\title{
Dolasetron Mesylate
}

National Cancer Institute

\section{Source}

National Cancer Institute. Dolasetron Mesylate. NCI Thesaurus. Code C1153.

An indole derivative with antiemetic activity. As a selective serotonin receptor antagonist,

dolasetron mesylate competitively blocks the action of serotonin at 5HT3 receptors,

resulting in suppression of chemotherapy- and radiotherapy-induced nausea and

vomiting. ( $\mathrm{NCl} 04)$ 